\title{
The Efficiency of Ankaferd Blood Stopper During the Dental Surgery in Hemorrhagic Diathesis: Case Series
}

\author{
Alper AKTAS ${ }^{1}$, Nuray ER ${ }^{1}$, Serkan KIRIS ${ }^{1}$, Osman T. KOSEOGLU ${ }^{1}$, Ibrahim C. HAZNEDAROGLU² \\ ${ }^{1}$ Hacettepe University Faculty of Dentistry Department of Oral Maxillofacial Surgery \\ ${ }^{2}$ Hacettepe University Faculty of Medicine Department of Haematology, Ankara, TURKEY
}

\begin{abstract}
Dental surgery in patients with hemorrhagic diathesis represents a great clinical challenge regarding the bleeding and complicated infections. There are various methods and materials for haemostasis of these patients. One of them is ABS (Ankaferd Blood Stopper), which has been approved for the clinical management of external post-surgical and dental surgery bleedings in Turkey. ABS could be effectively used both in individuals with normal haemostatic parameters and in patients with deficient primary hemostasis and/or secondary hemostasis. In this case series, total 11 patients who have various illnesses especially hemorrhagic diathesis are presented. ABS application demonstrated successful clinical management of the patients with various types of hemorrhagic diathesis.
\end{abstract}

Keywords: ABS, hemorrhagic diathesis, Dental surgery

\section{ÖZET}

Hemorajik Diyatezli Olgularda Dental Cerrahi Sırasında Ankaferd Blood Stopper'in Etkinliği

Hemorajik diyatezi bulunan diş cerrahi hastalarında ciddi kanama ve komplike enfeksiyonlar başta olmak üzere birçok sıkıntı görülebilir. Bu tip hastaların hemostazını sağlamak amaçlı çeşitli yöntem ve materyal mevcuttur. Bunlardan biri olan ABS (Ankaferd Blood Stopper), Türkiye'de eksternal kanamalarda kullanım için onay almıştır. ABS hem normal hemostatik parametreleri olan hastalarda hem de primer ve/veya sekonder hemostaz bozukluğu olan hastalarda etkin bir şekilde kullanilabilmektedir. Bu vaka serisinde, çeşitli hemorajik diyatezi bulunan toplam 11 hasta sunulmuştur. Çeşitli kanama bozuklukları bulunan bu hastalarda ABS kullanımı başarıı klinik sonuç göstermiştir.

Anahtar Kelimeler: ABS, Hemorajik diyatez, Dental cerrahi 


\section{INTRODUCTION}

Bleeding can cause significant morbidity and mortality in any clinical setting. Dental extractions and other similarly invasive procedures can be managed safely at the community dental practice in most situations. ${ }^{1-2}$ However, serious problems can be encountered during and after tooth extraction procedures with medically compromised bleeding-prone patients. Particularly, blood coagulation problems due to acquired or hereditary defects including advanced uremia without dialysis, platelet counts of less than $50000 / \mathrm{mm}^{3}$, liver failure, aplastic anemia and high dose cancer therapy and patients with multiple coagulapathies could need pre-surgical preparations. ${ }^{1-3}$ Hemorrhage, therefore, can be a major complication of routine dental treatments in patients with bleeding disorders.

There are various standard local hemostatic methods that are being used for the management of dental bleeding. Likewise, there are published reports about unsuccessfulness of the management of dental bleeding with the available methods. ${ }^{4-5}$ Studies about improvement of the hemostatic agents are continuing. ABS is a standardized herbal extract obtained from five different plants Thymus vulgaris, Glycyrrhiza glabra, Vitis vinifera, Alpinia officinarum and Urtica dioica. ${ }^{6} \mathrm{ABS}$ has been approved for the clinical management of external post-surgical and dental surgery bleedings in Turkey. ABS represents its unique hemostatic effect by promoting the very rapid $(<1$ second) formation of a protein network which acts as an anchor for vital physiological erythrocyte aggregation, covering the classical cascade model of the clotting system without independently acting on coagulation factors and platelets without disturbing individual coagulation factors. ${ }^{6}$ Phase-1 clinical study in order to demonstrate the safety of ABS is concluded as ABS is safe and efficient for humans. ${ }^{7}$ There are clinically successful reports about hemostasis of the cases with hemorrhagic diathesis..$^{8-11}$

This case series, demonstrated successful clinical management of the patients with various types of hemorrhagic diathesis.

\section{PATIENTS}

Total 11 patients who have various illnesses especially hemorrhagic diathesis are presented. Patients' biochemical and hematologic levels were evaluated by the hematologist who also gave written permissions for the extraction procedures. Essential findings of the patients are depicted in Table 1. Written informed consent was obtained from each subject for using ABS for the management of the bleeding. Bleeding control recorded by consecutive control of the sponge. Bleeding controlled over 3 minutes only in two of the patients. For other patients bleeding control time was 1-3 min or lower than 1 minute. No delayed type bleeding was recorded for teeth extractions. For the patients with further spontaneous gum bleeding, repetitive doses of ABS were recommended beside oral health improvement.

\section{DISCUSSION}

Dental surgery in patients with hemorrhagic diathesis represents a great clinical challenge regarding the bleeding and complicated infections. Patients who have bleeding disorders undergoing dental interventions can have postoperative excessive bleeding complications. $^{2}$ In this paper, we reported retrospective observations regarding the topical use of ABS hemostatic agent during dental surgery in the presence of hemorrhagic diathesis. Table 1 summarizes clinical status, type of hemorrhagic diathesis, and dental intervention in our patient cohort prone to bleeding. Ankaferd-induced formation of the protein network with vital erythroid aggregation covers the entire physiological hemostatic process. Mainly there are distinct important components of the Ankaferd-induced hemostatic network. Vital erythroid aggregation takes place with the spectrin and ankrin receptors on the surface of red blood cells. ${ }^{6}$ Bilgili et al. studied the efficiency of ABS in a swine bleeding model. They used ABS spray and tampon forms for hemostasis of superficial and deep skin lacerations, grade II liver and spleen injuries, grade II saphenous vein injury and grade IV saphenous artery injury. They informed about successful hemostasis except spleen model which was temporarily effective. They concluded that ABS was an effective hemostatic agent for superficial and deep skin lacerations and minor/moderate trauma injuries in a porcine bleeding model. ${ }^{12}$ Cipil et al. reported their study about hemostatic effect of ABS in rats pre-treated with warfarin. They showed that topical administration of ABS to amputed leg shortened the duration of bleeding significantly corresponding to control group and they recommended ABS hemorrhagic management of patients with deficient primary hemostasis in clinical medicine. ${ }^{13}$ Akgul et al demonstrated the efficiency of ABS over penile cavernosal tissue in rat model and concluded that $\mathrm{ABS}$ can be 
International Journal of Hematology and Oncology

TABLE 1. Clinical status, underlying hemorrhagic diathesis, the type of dental intervention, and observations regarding the topical ABS administration in the bleeding- prone patients

\begin{tabular}{|c|c|c|c|c|}
\hline Patients & Clinical status & Hemorrhagic diathesis & Dental intervention & $\begin{array}{l}\text { Observations during/ after } \\
\text { topical ABS administration }\end{array}$ \\
\hline $\begin{array}{l}\text { 57-year-old } \\
\text { female }\end{array}$ & $\begin{array}{l}\text { End-stage liver failure } \\
\text { Hipersplenism } \\
\text { Pancytopenia }\end{array}$ & $\begin{array}{l}\text { Defective } 1^{0} \text { haemostasis } \\
\text { (refractory thrombocytopenia } \\
\text { Defective } 2^{0} \text { haemostasis } \\
\text { (high INR) }\end{array}$ & $\begin{array}{l}\text { Number } 48 / 24 / 38 \\
\text { dental extractions }\end{array}$ & $\begin{array}{l}\text { Bleeding controlled in } 1-3 \mathrm{~min} \text {. } \\
\text { the presence of the both the } \\
\text { defects in primary and } \\
\text { secondary haemostasis }\end{array}$ \\
\hline $\begin{array}{l}\text { 62-year-old } \\
\text { female } \\
\text { (Figure 1) }\end{array}$ & $\begin{array}{l}\text { Platelet secretion defect } \\
\text { Activated protein C } \\
\text { resistance / venous } \\
\text { thrombosis } \\
\text { Hyperlipidemia }\end{array}$ & $\begin{array}{l}\text { Defective } 1^{0} \text { haemostasis } \\
\text { (thrombocyte dysfunction) } \\
\text { Concomitant hypercoa- } \\
\text { gulability }\end{array}$ & $\begin{array}{l}\text { Number } 36 \\
\text { dental extraction }\end{array}$ & $\begin{array}{l}\text { Bleeding controlled in } 1-3 \mathrm{~min} \text {. } \\
\text { in the presence of the defect in } \\
\text { primary haemostasis. } \\
\text { No thrombotic event. }\end{array}$ \\
\hline $\begin{array}{l}\text { 43-year-old } \\
\text { Male (Figure 2) }\end{array}$ & Severe Haemophilia A & $\begin{array}{l}\text { Defective } 2^{0} \text { haemostasis } \\
(\mathrm{F} \mathrm{VIII}<1 \%)\end{array}$ & $\begin{array}{l}\text { Multiple dental } \\
\text { extractions } \\
\text { (total } 9 \text { teeth\% }\end{array}$ & $\begin{array}{l}\text { Bleeding controlled in } 1-3 \text { min. } \\
\text { in the presence of both the } \\
\text { defect in secondary haemos- } \\
\text { tasis. } \\
\text { (Decreased factor requirement) }\end{array}$ \\
\hline $\begin{array}{l}\text { 55-year-old } \\
\text { Male }\end{array}$ & $\begin{array}{l}\text { Heart failure } \\
\text { Uncontrolled diabetes }\end{array}$ & $\begin{array}{l}\text { Defective haemostatic } \\
\text { disorder and impaired } \\
\text { wound healing due to } \\
\text { systemic disorders }\end{array}$ & Total 16 teeth & $\begin{array}{l}\text { Bleeding controlled in less than } \\
1 \text { min. in the presence of the } \\
\text { defect in secondary } \\
\text { haemostasis. }\end{array}$ \\
\hline $\begin{array}{l}\text { 8-year-old } \\
\text { Male }\end{array}$ & $\begin{array}{l}\text { Immune thrombocytopenic } \\
\text { purpura }\end{array}$ & $\begin{array}{l}\text { Defective } 1^{0} \text { haemostasis } \\
\text { (refractory thrombocytopenia) }\end{array}$ & $\begin{array}{l}\text { Lower left deciduous } \\
\text { molar dental } \\
\text { extraction }\end{array}$ & $\begin{array}{l}\text { Bleeding controlled in less than } \\
1 \text { min. in the presence of the } \\
\text { defect in primary hemostasis }\end{array}$ \\
\hline $\begin{array}{l}\text { 35-year-old } \\
\text { Female }\end{array}$ & Clonal aplastic anemia & $\begin{array}{l}\text { Defective } 1^{0} \text { haemostasis } \\
\text { (refractory thrombocytopenia) } \\
\text { Prone to infection due to } \\
\text { leukopenia }\end{array}$ & $\begin{array}{l}\text { Number } 38 \text { dental } \\
\text { extraction }\end{array}$ & $\begin{array}{l}\text { Bleeding controlled in less than } \\
1 \text { min. in the presence of the } \\
\text { defect in primary hemostasis }\end{array}$ \\
\hline $\begin{array}{l}\text { 15-year-old } \\
\text { Male (Figure 3) }\end{array}$ & Glanssmann Disease & $\begin{array}{l}\text { Defective } 1^{0} \text { haemostasis } \\
\text { (thrombocyte dysfunction) }\end{array}$ & $\begin{array}{l}\text { Chronic spontaneous } \\
\text { gum bleeding leading } \\
\text { to anemia requiring } \\
\text { transfusion }\end{array}$ & $\begin{array}{l}\text { Bleeding controlled in less than } \\
1-3 \text { min. in the presence of the } \\
\text { defect in primary haemostasis }\end{array}$ \\
\hline $\begin{array}{l}\text { 30-year-old } \\
\text { Female }\end{array}$ & Glanssmann Disease & $\begin{array}{l}\text { Defective } 1^{0} \text { haemostasis } \\
\text { (thrombocyte dysfunction) }\end{array}$ & $\begin{array}{l}\text { Chronic spontaneous } \\
\text { gum bleeding leading } \\
\text { to anemia requiring } \\
\text { transfusion }\end{array}$ & $\begin{array}{l}\text { Bleeding controlled in less than } \\
1-3 \text { min. in the presence of the } \\
\text { defect in primary haemostasis }\end{array}$ \\
\hline 29-year-old & Clonal aplastic anemia & $\begin{array}{l}\text { Defective } 1^{0} \text { haemostasis } \\
\text { (refractory thrombocytopenia) } \\
\text { Prone to infection due to } \\
\text { leukopenia }\end{array}$ & $\begin{array}{l}\text { Number } 12,22,31 \\
\text { extractions }\end{array}$ & $\begin{array}{l}\text { Bleeding controlled in less than } \\
1 \text { min. in the presence of the } \\
\text { defect in primary hemostasis }\end{array}$ \\
\hline $\begin{array}{l}\text { 20-year-old } \\
\text { Female }\end{array}$ & $\begin{array}{l}\text { Thalessemia intermedia } \\
\text { Hemochromatosis }\end{array}$ & $\begin{array}{l}\text { Defective haemostatics } \\
\text { disorder and impaired } \\
\text { wound healing due to } \\
\text { systemic disorders }\end{array}$ & $\begin{array}{l}\text { Chronic spontaneous } \\
\text { bleeding leading to } \\
\text { anemia requiring } \\
\text { transfusion }\end{array}$ & $\begin{array}{l}\text { Bleeding controlled in less than } \\
1 \mathrm{~min} \text {. in the presence of the } \\
\text { defect in primary hemostasis }\end{array}$ \\
\hline $\begin{array}{l}\text { 38-year-old } \\
\text { Female }\end{array}$ & $\begin{array}{l}\text { Rheumatic heart disease } \\
\text { (Mitral valve replacement) }\end{array}$ & $\begin{array}{l}\text { Defective } 2^{0} \text { haemostasis } \\
\text { (high INR due to chronic } \\
\text { warfarin use) }\end{array}$ & $\begin{array}{l}\text { Number } 18,48 \text { dental } \\
\text { extractions }\end{array}$ & $\begin{array}{l}\text { Bleeding controlled in less than } \\
1 \text { min. in the presence of the } \\
\text { defect in primary hemostasis }\end{array}$ \\
\hline
\end{tabular}




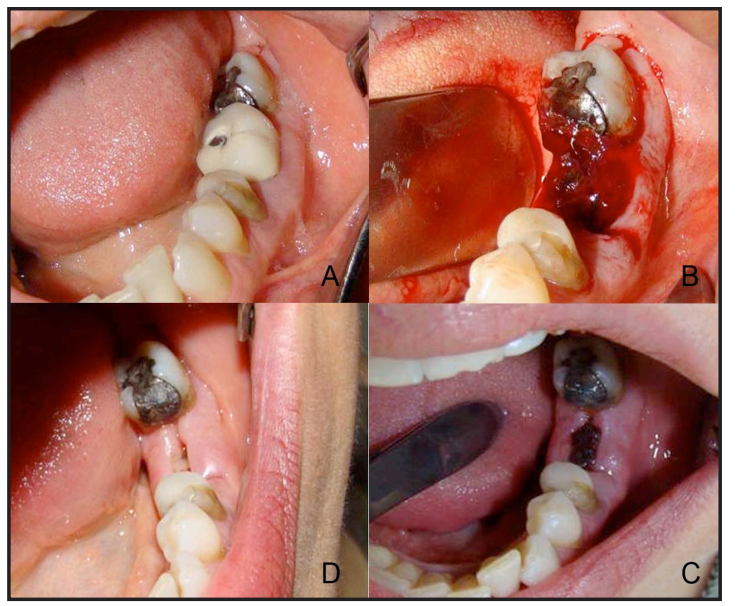

Figure 1. A: Tooth number 36 that going to be extracted

B: ABS applied extracted socket.

C: wound healing of the socket after 24 hours

D: wound healing of the socket after 5 days

used in cavernosal surgeries due to its haemostatic and anti inflammatory effects. ${ }^{14}$ Further, a number of clinical case reports have demonstrated successful bleeding management by ABS applied topically over uncontrolled bleedings. ${ }^{11,15-17}$ Those findings suggested that ABS has a strong potential of usage in medical practice, particularly in dentistry.

ABS could be effectively used both in individuals with normal haemostatic parameters and in patients with deficient primary hemostasis and/or secondary hemostasis. The safety and efficacy of ABS in dental surgery and bleedings have been shown previously in 25 patients with normal hemostasis. ${ }^{18}$ There was no statistically and clinically significant difference

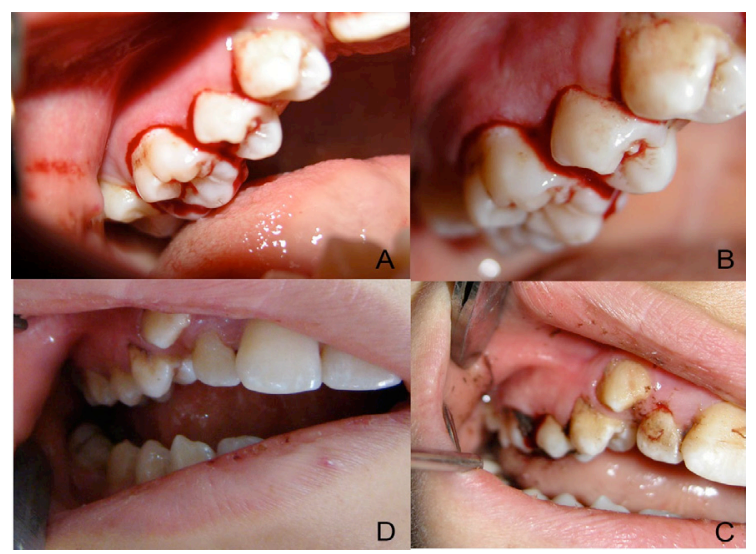

Figure 3. A: Spontaneous bleeding especially from interdental papilla region

B: bleeding from 15,16 teeth region

C: ABS applied and in seconds hemostasis achieved

D: 24 hours later of ABS application

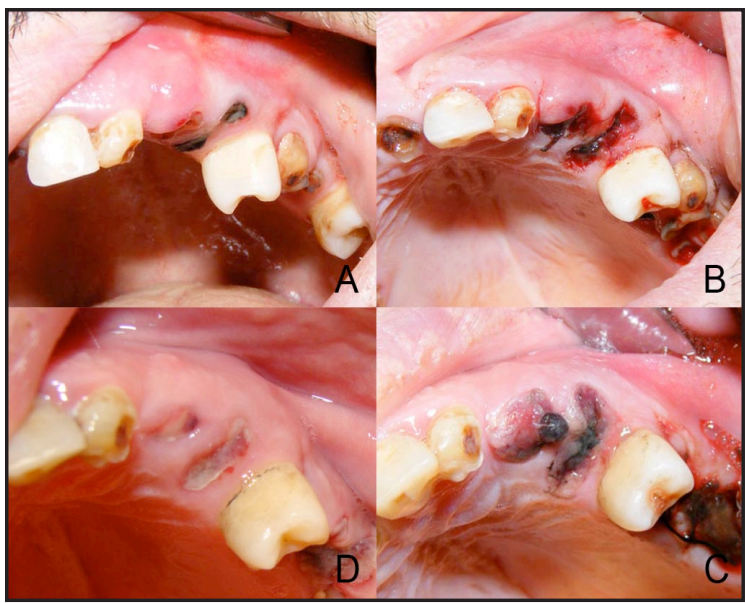

Figure 2. A: Tooth number 23 and 24 that going to be extracted

B: After seconds of immediately applied ABS

C: 24 hours later after the extraction

D: 4 days later after the extraction

between the pre- and post treatment values of the serum levels of blood urea nitrogen, creatinine, alanine aminotransferase, aspartate aminotransferase, alkaline phosphatase, total and direct bilirubin, total protein, albumin, uric acid, creatinine kinase, cystatin C, sodium and potassium levels. Hemostatic efficiency without any toxicity of ABS in patients with hemorrhagic diathesis was also observed in this study. ${ }^{18}$ Hemostasis was successful and they healed uneventfully. In this study, postoperative evaluations regarding hematological, biochemical, hepatic and renal functions had not been performed.

Ak et al. reported teeth extraction of 5 hemophiliac patients. They used ABS for the management of bleeding and reported that ABS reduced hemorrhage after treatment which is similar to our case series. ${ }^{10}$ Leblebisatan et al., used ABS for 12 pediatric patient with hemorrhagic diathesis and reported that ABS had stopped bleeding successfully except one patient. They concluded that, ABS was effective for clinical usage of such patients. ${ }^{8}$ Cakarer et al, evaluated bleeding time of 25 patients who were on antithrombotic therapy and needed simple exractions. Bleeding time for ABS group was statistically lower according to control group..$^{9}$ Turgut et al., reported 8 cases which have haemorrhagic diathesis and had dental or external bleedings. ${ }^{11}$ They achieved bleeding control of all cases and concluded that these results were promising for the usage of ABS in anticoagulated patients and hereditary bleeding disorders such as clotting factor deficiencies. ${ }^{11}$ 
These published reports which are listed over and this case series are important as exhibiting the effectiveness of ABS over external bleedings of dental patients who have hemorrhagic diathesis. Further investigations on the exciting features of ABS as a hemostatic, wound healing accelerator, and anti-infective agent are still in progress.

\section{REFERENCES}

1. Lockhart PB, Gibson J, Pond SH, Leitch J. Dental management considerations for the patient with an acquired coagulopathy. Part 1: Coagulopathies from systemic disease. $\mathrm{Br}$ Dent J 195: 439-445, 2003.

2. Garfunkel AA, Galili D, Findler M, et al. Bleeding tendency: a practical approach in dentistry. Compend Contin Educ Dent 20: 836-838, 1999.

3. Israels S, Schwetz N, Boyar R, McNicol A. Bleeding disorders: characterization, dental considerations and management. J Can Dent Assoc 72: 827, 2006.

4. Nishide N, Nishikawa T, Kanamura N. Extensive bleeding during surgical treatment for gingival overgrowth in a patient on haemodialysis: a case report and review of the literature. Aust Dent J 50: 276-281, 2005.

5. Franchini M, Rossetti G, Tagliaferri A, et al. Dental procedures in adult patients with hereditary bleeding disorders: 10 years experience in three Italian Hemophilia Centers. Haemophilia 11: 504-509, 2005.

6. Goker H, Haznedaroglu IC, Ercetin S, et al. Haemostatic actions of the folkloric medicinal plant extract ankaferd blood Stopper (R). J Int Med Res 36: 163-170, 2008.

7. Balcik SO, Koroglu M, Cipil H, et al. A placebo-controlled, randomized double-blinded, cross-over phase 1 clinical study to demonstrate safety of Ankaferd Blood Stopper topical usage in healthy volunteers. UHOD 22: 1-8, 2012.

8. Leblebisatan G, Bay A, Karakus SC, et al. Topical Ankaferd hemostat application for the management of oral cavity bleedings in children with hemorrhagic diathesis. Blood Coagul Fibrinolysis 23: 494-497, 2012.

9. Cakarer S, Eyupoglu E, Gunes CO, et al. Evaluation of the Hemostatic Effects of Ankaferd Blood Stopper During Dental Extractions in Patients on Antithrombotic Therapy. Clin Appl Thromb Hemost 19: 96-99, 2013.

10. Ak G, Cakir O, Kazancioglu HO, Zulfikar B. The use of a new hemostatic agent: Ankaferd Blood Stopper in hemophiliacs. Haemophilia 16(Suppl 4): 51, 2010.
11. Turgut M, Tutken F, Celebi N, et al. Topical Ankaferd Bloodstopper in the Management of Critical Bleedings due to Hemorrhagic Diathesis. UHOD 21: 160-165, 2011.

12. Bilgili H, Kosar A, Kurt M, et al. Hemostatic Efficacy of Ankaferd Blood Stopper $(\mathrm{R})$ in a Swine Bleeding Model. Med Prin Pract 18: 165-169, 2009.

13. Cipil HS, Kosar A, Kaya A, et al. In Vivo Hemostatic Effect of the Medicinal Plant Extract Ankaferd Blood Stopper in Rats Pretreated With Warfarin. Clin Appl Thromb-Hem 15: 270276, 2009.

14. Akgul T, Huri E, Ayyildiz, et al. Haemostatic and Histopathological Effects of Ankaferd Blood Stopper, on Penile Cavernosal Tissue in Rats. UHOD Int J HematolOncol 19: 159165, 2009.

15. Ibis M, Kurt M, Onal IK, Haznedaroglu IC. Successful Management of Bleeding Due to Solitary Rectal Ulcer via Topical Application of Ankaferd Blood Stopper. J Altern Complem Med 14: 1073-1074, 2008.

16. Kurt M, Kacar S, Onal IK, et al. Ankaferd Blood Stopper as an effective adjunctive hemostatic agent for the management of life-threatening arterial bleeding of the digestive tract. Endoscopy 40(Suppl 2): 262, 2008.

17. Kurt M, Disibeyaz S, Akdogan M, et al. Endoscopic application of Ankaferd blood stopper as a novel experimental treatment modality for upper gastrointestinal bleeding: A case report. Am J Gastroenterol 103: 2156-2158, 2008.

18. Ercetin S, Haznedaroglu IC, Kurt M, et al. Safety and Efficacy of Ankaferd Blood Stopper in Dental Surgery. UHOD 20: 1-5, 2010.

\section{Correspondence}

Dr. Alper AKTAŞ

Hacettepe Üniversitesi Diş Hekimliği Fakültesi

Maksillofasiyal Cerrahi Anabilim Dalı

06100 Sihhiye/Ankara/TURKEY

Tel: (+90.312) 3052220

Fax: (+90.312) 3104440

e-mail: alperaktas@gmail.com 